\title{
Disseminated Tuberculosis During the Course of Behçet's Disease: A Case Report
}

\author{
Behçet Hastalığı Seyrinde Görülen Dissemine Tüberküloz: Olgu Sunumu
}

\author{
İbak GÖNEN, ${ }^{1}$ Mustafa ÖZŞAHIN,${ }^{2}$ Mustafa YILDIRIM, ${ }^{1}$ Davut ÖZDEMİR, ${ }^{1}$ Leyla YILMAZ AYDIN, ${ }^{3}$ \\ Ali KUTLUCAN, ${ }^{4}$ Hakan TURAN,${ }^{5}$ Ahmet ŞAHIN,${ }^{1}$ Ramazan BÜYÜKKAYA ${ }^{6}$ \\ ${ }^{1}$ Department of Infectious Diseases, Medical Faculty of Düzce University, Düzce, Turkey; \\ ${ }^{2}$ Department of Physical Medicine and Rehabilitation, Medical Faculty of Düzce University, Düzce, Turkey; \\ ${ }^{3}$ Department of Chest Diseases, Medical Faculty of Düzce University, Düzce, Turkey; \\ ${ }^{4}$ Department of Internal Medicine, Medical Faculty of Düzce University, Düzce, Turkey; \\ ${ }^{5}$ Department of Dermatology, Medical Faculty of Düzce University, Düzce, Turkey; \\ ${ }^{6}$ Department of Radiology, Medical Faculty of Düzce University, Düzce, Turkey
}

In this article, a 22 year-old male with disseminated tuberculosis during the course of Behçet's disease who was admitted with the complaints of fever, headache and fatigue was presented. The initial diagnosis was neuroBehçet's syndrome. Tuberculosis during the course of rheumatic diseases are often associated with the use of TNF-alpha blockers. In our case, the patient experienced severe disseminated tuberculosis, despite being TNFalpha blocker-naive. To the best of our knowledge, this is the first case of tuberculosis with such a disseminated course developed in a patient with Behçet's disease who received conventional immunosuppressive treatment.

Key words: Behçet's diseases; disseminated tuberculosis; immunosupressive treatment.

Behçet's disease is a chronic inflammatory multisystemic vasculitis without a clearly established etiology and pathogenesis. ${ }^{[1]}$ It is common in the Middle East and Asia, including Japan, and has also been seen in Turkey. ${ }^{[2,3]}$ The incidences of severe bacterial infections have increased due to the increasingly widespread use of immunosuppressive agents in Behçet's disease. Increases in tuberculosis infection due to the use of
Bu yazıda, ateş, baş ağrısı ve yorgunluk şikayetiyle başvuran, Behçet hastalığı seyrinde dissemine tüberküloz olan, 22 yaşında bir erkek hasta sunuldu. Başlangıç tanısı nöro-Behçet sendromuydu. Romatizmal hastalıkların seyrinde görülen tüberküloz, genellikle TNF-alfa blokerlerinin kullanımıyla ilişkilendirilmektedir. Olgumuzda, hasta TNF-alfa blokeri kullanmamış olmasına rağmen, dissemine tüberküloz gelişti. Mevcut bilgilerimiz doğrultusunda, bu olgu, konvansiyonel immünosüpresif tedavi alan bir Behçet hastasında gelişen bu denli yaygın seyreden ilk tüberküloz olgusudur.

Anahtar sözcükler: Behçet hastalığı; dissemine tüberküloz; immunosüpresif tedavi.

tumor necrosis factor-alpha (TNF- $\alpha$ ) blockers have been especially noticeable. ${ }^{[4-6]}$ In this report, we present a multi-systemic case of tuberculosis in a patient with Behçet's disease who presented with complaints of fever, headache, and fatigue. He was initially considered to have neuro-Behçet's disease. This case is unique because it had a multi-systemic course even though TNF- $\alpha$ blockers were not used.

Received: October 20, 2011 Accepted: December 25, 2011

Correspondence: İbak Gönen, M.D. Düzce Üniversitesi Tıp Fakültesi Enfeksiyon Hastalıkları Anabilim Dalı, 81650 Düzce, Turkey.

Tel: +90 380 - 5421416 e-mail: dribak77@hotmail.com

C2012 Turkish League Against Rheumatism. All rights reserved. 


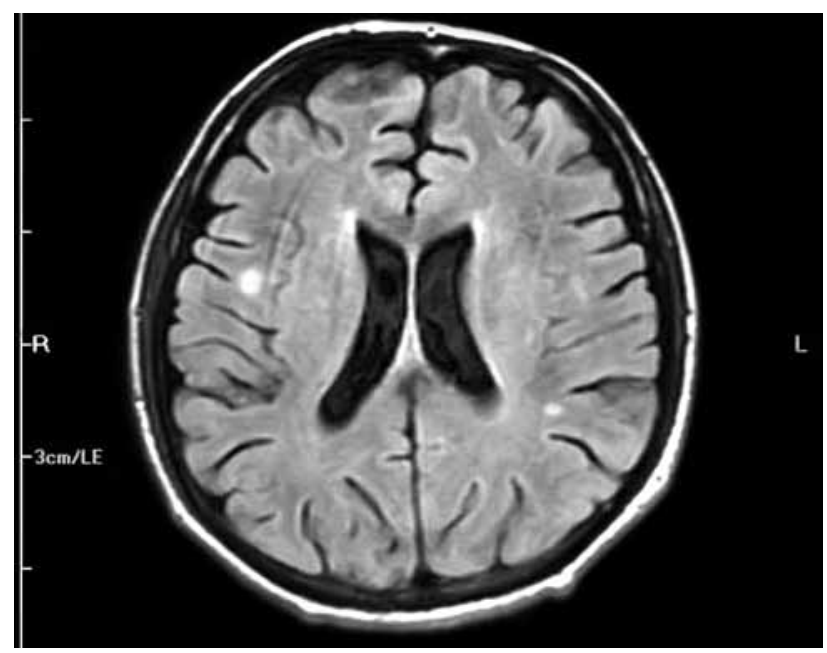

Figure 1. Magnetic resonance imaging of the brain showing tuberculous granuloma.

\section{CASE REPORT}

A 22-year-old male patient was presented to the emergency room of our hospital with complaints of fever, headache, and fatigue which had been occurring for 10 days. The medical history revealed that he had been diagnosed as having Behçet's disease in 2007 and had been using prednisolone since the time of diagnosis. The dosage of prednisolone was increased up to $64 \mathrm{mg} /$ day by the supervising clinician. Cyclosporine-A had been added to the treatment

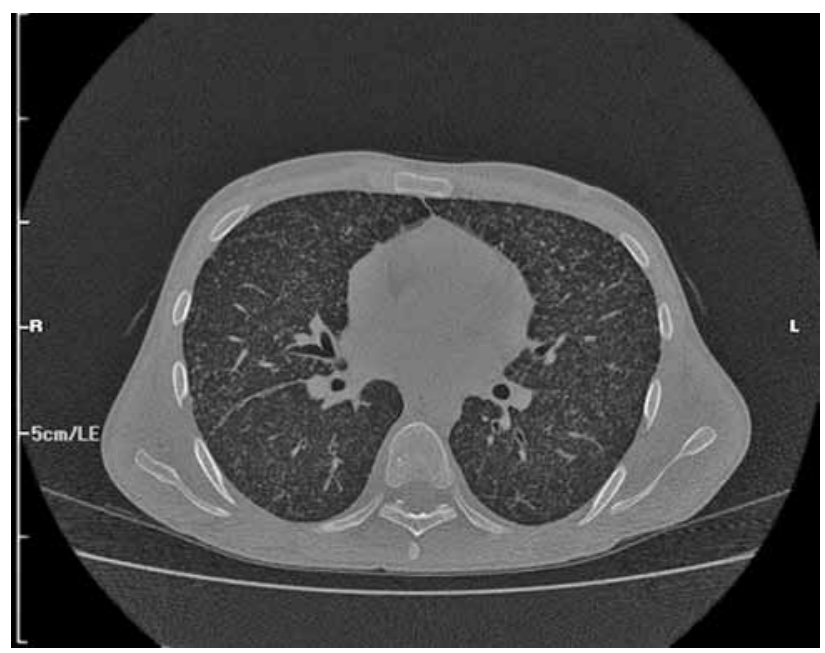

Figure 2. High resolution computed tomography of the thorax showing millary tuberculosis.

at $100 \mathrm{mg} /$ day two months previously due to eye involvement but was discontinued after one week due to side effects of fever, fatigue, and headache. The patient was prescribed azathioprine at $100 \mathrm{mg}$ /day on the follow-up visit, and he had been using this drug for nearly 10 days prior to being admitted to our hospital. The physical examination findings revealed a body temperature of $39.8{ }^{\circ} \mathrm{C}$, arterial blood pressure of $110 / 70 \mathrm{mmHg}$, and a heart rate of 112 per minute. Neck stiffness was minimally positive. He had swelling and sensitivity on palpation in the right
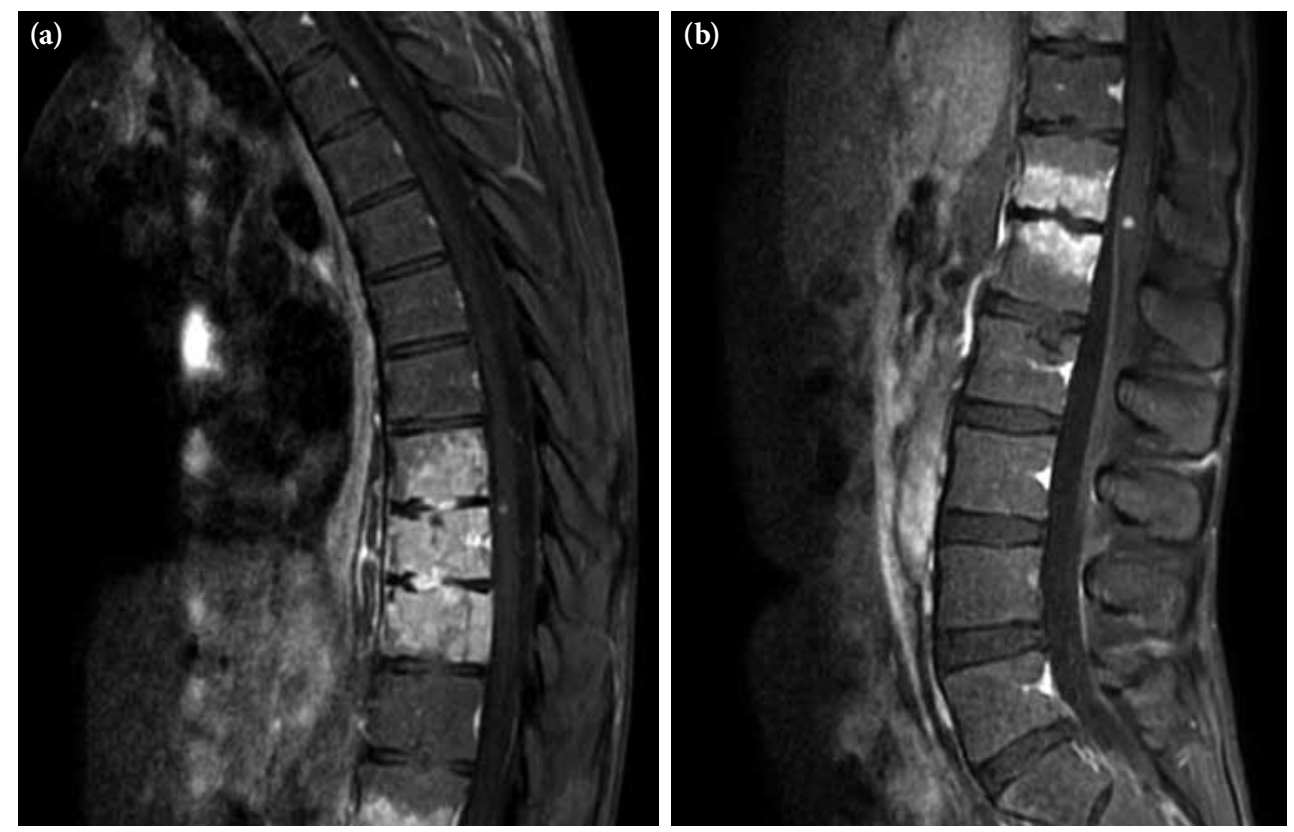

Figure 3. (a) Widespread lytic lesions in the vertebra corpuses and the tissue swelling adjacent to the vertebra (Pott's disease) and spinal tuberculous granuloma. (b) Lumber vertebral magnetic resonance imaging showing Pott's disease and spinal tuberculous granuloma. 
scrotal region that had started three months earlier. Laboratory examinations were as follows: leukocyte count $7.400 / \mathrm{mm}^{3}$, erythrocyte sedimentation rate $87 \mathrm{~mm} / \mathrm{h}$, C-reactive protein: $13.4 \mathrm{mg} / \mathrm{dl}$ in cerebrospinal fluid (CSF) analysis, leukocyte count: 20/ $\mathrm{mm}^{3}$, protein: $200 \mathrm{mg} / \mathrm{dL}$, and glucose: $27 \mathrm{mg} / \mathrm{dL}$ (blood glucose: $94 \mathrm{mg} / \mathrm{dL}$ ). There was no growth on the CSF culture. A chest X-ray was normal. Since the CSF findings and physical examination results could not rule out bacterial meningitis, he was started on ceftriaxone $2 \times 2$ gr intravenously. He had no regression of complaints in the first week of treatment, and his antibiotic treatment was discontinued. Internal disease and neurology consultations in conjunction with the clinical findings and CSF results led to a diagnosis of neuro-Behçet's disease. Scrotal ultrasound screening was consistent with epididymitis. A large number of leukocytes were observed in the material aspirated from the testis (90\% lymphocyte in nature). EhrlichZiehl-Neelsen (EZN) staining detected acid-resistant bacteria. Treatment with isoniazid, ethambutol, pyrazinamide, and rifampicin was initiated under the diagnosis of testis tuberculosis. Subsequently, chest high resolution computed tomography (HRCT) and brain magnetic resonance imaging (MRI) were done. The chest HRCT result was consistent with miliary tuberculosis (Figure 1), and the brain MRI revealed findings were consistent with tuberculous granuloma and tuberculous meningitis (Figure 2). The vertebral MRI showed that widespread lytic lesions in the vertebra corpuses and the tissue swelling adjacent to the vertebra were consistent with Pott's disease and spinal granuloma (Figure $3 \mathrm{a}$ and $3 \mathrm{~b}$ ). Based on these examinations, the patient was considered to have disseminated tuberculosis (testicular tuberculosis, miliary tuberculosis, tuberculosis meningitis, spinal granuloma, and Pott's disease). The anti-tuberculous treatment was revised with the ethambutol being replaced by streptomycin. The patient's body temperature returned to normal on the eighth day of treatment. The patient, whose general condition was observed to improve, is still receiving the treatment.

\section{DISCUSSION}

Recently, increases in the incidences of infectious diseases that have occurred in the course of autoimmune diseases and the infection-related morbidity and mortality associated with the use of potent immunosuppressive agents are more noticeable. Cases of pulmonary and extrapulmonary tuberculosis have been particularly observed in association with newly introduced TNF- $\alpha$ blockers. A majority of the tuberculosis cases occurring in the course of various autoimmune and rheumatologic diseases, including Behçet's disease, have been associated with the use of TNF- $\alpha$ blockers. ${ }^{[4-6]}$ Therefore, performing screenings for tuberculosis before these treatments and administering prophylaxis upon detection of latent tuberculosis is required. ${ }^{[4,7]}$ Despite negative screening and isoniazid prophylaxis, tuberculosis cases have been reported. ${ }^{[5-7]}$ In the present case, the patient experienced severe disseminated tuberculosis despite never using a TNF- $\alpha$ blocker. Only a few cases of tuberculosis have been reported in the literature that were diagnosed in a patient with Behçet's disease who was undergoing conventional immunosuppressive therapy ${ }^{[8,9]}$ Therefore, the question of whether or not to perform tuberculosis screening or prophylaxis during treatment of the autoimmune diseases with systemic conventional immunosuppressive therapies has been raised. This question gains further importance in countries where tuberculosis is frequently observed, and an answer is needed. Some authors recommend routine screening and prophylaxis in psoriasis. ${ }^{[10]}$ To the best of our knowledge, this is the first case of tuberculosis with such a disseminated course which has occurred in a patient with Behçet's disease undergoing conventional immunosuppressive treatment.

In conclusion, tuberculosis infection can still occur in the course of Behçet's disease without the use of TNF- $\alpha$ blockers. In fact, severe tuberculosis forms such as meningeal tuberculosis, spinal tuberculosis, and miliary tuberculosis may occur, as was seen in our patient. It is important to differentiate between such infectious diseases and the organ involvement of Behçet's disease so that the appropriate treatment can be initiated. We also believe that the necessity of performing screenings for tuberculosis before conventional immunosuppressive treatments should be investigated.

\section{REFERENCES}

1. Yazıcı H, Yurdakul S, Hamuryudan V. Behçet's syndrome. In: Klippel HJ, Dieppe PA, editors. Rheumatology. 2nd ed. Spain: Mosby; 1998. p. 7.21, 1-6.

2. Kaklamani VG, Vaiopoulos G, Kaklamanis PG. Behçet's Disease. Semin Arthritis Rheum 1998;27:197-217.

3. Tatlıcan S. Anti-TNF agents in Behçet's disease treatment. Turk J Rheumatol 2009;24:27-38.

4. Keane J, Gershon S, Wise RP, Mirabile-Levens E, Kasznica J, Schwieterman WD, et al. Tuberculosis associated with infliximab, a tumor necrosis factor alpha-neutralizing agent. N Engl J Med 2001;345:1098-104. 
5. Sichletidis L, Settas L, Spyratos D, Chloros D, Patakas D. Tuberculosis in patients receiving anti-TNF agents despite chemoprophylaxis. Int J Tuberc Lung Dis 2006;10:1127-32.

6. Hirano Y, Kojima T, Kanayama Y, Ishikawa H, Ishiguro N. A case of lung tuberculosis in a patient with rheumatoid arthritis treated with infliximab after antituberculosis chemoprophylaxis with isoniazid. Mod Rheumatol 2009;19:323-8.

7. Skvara H, Duschek N, Karlhofer F. De novo tuberculosis during infliximab therapy in a patient with Behçet disease. J Dtsch Dermatol Ges 2009;7:616-9. [Abstract]

8. Iliopoulos A, Kedikoglou S, Laxanis S, Kourouklis S,
Katsaros E. A case of tuberculous meningoencephalitis in a patient with Behçet's disease. Clin Rheumatol 2006;25:121-2.

9. Demircan C, Kaya N, Emirler C, Tuncer I, Erkan E. Tuberculosis in a patient with Behçet's disease using syclosporin-A. OMU Tip Dergisi 1991;8:365-8.

10. Doherty SD, Van Voorhees A, Lebwohl MG, Korman NJ, Young MS, Hsu S. National Psoriasis Foundation consensus statement on screening for latent tuberculosis infection in patients with psoriasis treated with systemic and biologic agents. J Am Acad Dermatol 2008;59:209-17. 